\title{
"Ah! Our very own Juliet Bravo, or is it Jill Gascoine?" Ashes to Ashes and representations of gender
}

\author{
Ben Lamb
}

Ashes to Ashes (2008-10) combines two previously separate ideologies of the British police series. Co-creators Matthew Graham and Ashley Pharoah achieve this hybridity by slightly altering their Life on Mars (2006-2007) format. DI Sam Tyler (John Simm), who previously solved crimes alongside DCI Gene Hunt (Philip Glenister) in 1970s Manchester, is now replaced by DI Alex Drake (Keeley Hawes) in 1980s London. Life on Mars' nostalgic reincarnation of the male dominated action series shot on film in the 1970s, for example The Sweeney (1975-78) and The Professionals (1977-83), is now integrated with police series of the 1980s that centred on female leads. These series were shot in the studio and challenged sexism within the force, for example Juliet Bravo (1980-85) and The Gentle Touch (198084). This chapter argues that Drake's character who, like Tyler, finds herself trapped in the past and is struggling to find a way back to the present, represents this female strand of the police genre and Hunt represents the macho action subgenre. Therefore, Fenchurch CID in Ashes to Ashes is an office space that opens a dialogue between the 1970s and 1980s representations of detective work, thus scrutinising the shortcomings of each gendered approach. This office interior is significant because it is used as the narrative focal point of the series much like studio-shot police dramas of the 1980s. Adopting Alan Clarke's methodology used to compare Dixon of Dock Green (1955-76) to The Sweeney, this chapter will analyse "the clustering of ideological elements...thus locating the difference between genres not at the level of iconographic content but at the deeper structured level of ideology'. ${ }^{1}$ To deconstruct these ideological elements this chapter will analyse first the differences 
between Hunt and Jack Regan (John Thaw) of The Sweeney and between Alex Drake and Maggie Forbes (Jill Gascoine) of The Gentle Touch. These key dissimilarities will be identified through a close comparison of the office set designs of each series and of how each office frames these principal characters differently. These spatial analyses will unearth the nuanced sexual politics that operate in each station to determine how Ashes to Ashes negotiates between these previous representations of gender. With the sexual politics established, the chapter will then provide a comparison between Drake's and Hunt's highly different interrogation methods to detect the differences in their attitudes towards key sociological issues. The purpose of these comparisons between Ashes to Ashes and its predecessor series, and between Hunt and Drake, is to identify how the ideology of the British detective series is reformulated over time.

DCI Hunt is widely regarded as being 'strongly reminiscent' of Regan due to his rejection of analytical procedures, reliance on instinct and penchant for violence. ${ }^{2}$ Hunt and Regan adhere to a particularly 'aggressive' model of hegemonic masculinity realised through their regular scotch drinking and frequent law breaking. ${ }^{3}$ These unorthodox methods are, with regards to Regan, 'at odds with the new methods which his superiors' are 'trying to introduce'. ${ }^{4}$ Similarly, Matthew Graham likens Hunt to 'an old grizzly Sherriff now in a town... where the railway is coming and bringing modern ideas'. ${ }^{5}$ Beyond these obvious similarities there is, however, one significant difference that needs to be addressed; alienation. Regan is isolated within the Flying Squad as his position is threatened by privately educated 'bureaucrats' and younger, intellectual recruits. Regan's desk is placed in the corner of the communal squad office, distanced from the other detectives. This desk location then moves to the opposite corner of the squad office without narrative recognition in the opening episode of series two, 'Chalk and Cheese' (1 September 1975). Regan's isolation is further symbolised as his back is now facing the reserve room, where officers collectively work 
together at a large communal table. This repositioning, bereft of narrative explanation, suggests that Regan is being moved around by a management who are unsure of where he fits into the Flying Squad. As producer Ted Childs stated,

With some justification Regan fears his wings are about to be clipped. The new top detective is likely to be much more an "organisation man" working through committee and much more heavily dependent on specialist forensic and other services. $^{6}$

The Metropolitan Police is rapidly modernising and Regan's physical methods are gradually being eradicated thus isolating him from the other detectives. Due to this isolation Regan displays little respect for the squad office. In 'Cover Story' (20 February 1975) Regan shaves at his desk and then blows his facial hair into the path of two detectives walking past who feel obliged to apologise. Regan effectively marks out his territory to protect his corner of the office from the rapidly modernising bureaucratic culture of Scotland Yard.

In stark contrast to Regan, Hunt is in charge of his own CID unit and thrives on being the centre of attention. Hunt's office is positioned inside the communal squad office, separated from his colleagues by a glass partition. This glass partition enables Hunt to actively involve himself in all of his colleagues' cases thus providing them with a relatively egalitarian workspace. Four large communal desks are positioned in front of Hunt's office. Two desks are placed either side of Hunt's office door with detectives usually sitting around their outside edges. As the detectives are positioned around Hunt's office in this way, Hunt is the focal point of this collective squad office space and all look to him for guidance. Hunt also hangs a poster of his face on the front of his office door. His photo is defaced with a lion's mane accompanied by the words 'Manc Lion'. This poster demonstrates how instead of hiding himself away in a corner, like Regan who marks his territory in a fight for survival, 
Hunt actively wants people to be kept in awe of his animalistic masculinity. Much like the Flying Squad of The Sweeney Hunt faces endless pressures from a modernising Met. Instead of hiding himself away, Hunt faces up to the superiors who question his methods with a certain totemic power with which the office design provides him. When Lord Scarman (Geoffrey Palmer), during an impromptu inspection in episode 1.8 (27 March 2008), stands in the centre of the office publicly condemning Hunt for the way in which his department is run, Hunt initially concedes and walks towards his office door. However when Scarman threatens Hunt saying, 'I'll be keeping a beady eye on you DCI Hunt' Hunt turns back around from his office and squares up to Scarman claiming,

'Well you can take this home in your Harrods pipe and smoke it...You can despise us. You can disown us, you can even try and close us down but you will never break us because we are police officers. We are brothers. We are un-bloody breakable'.

These closing remarks are accompanied by triumphant non-diegetic choir music composed by Edmund Butt. The two-shot of Scarman and Hunt tilts to a low angle cutting the back of Scarman's head off from view and framing Hunt in his own close-up. Hunt's speech has been a tour de force. The rhetoric mirrors the Saint Crispin's Day speech from Shakespeare's Henry $V$ and inspires all the detectives to rise to their feet in applause causing Scarman to leave without uttering a word. Scarman is emasculated by Hunt for his upperclass bureaucratic position. Throughout their confrontation both men are framed by a long shot that replicates the cinematography used to frame stand-offs in spaghetti westerns. Challenged in this way, Scarman is unable to engage in a conflict with Hunt under such aggressive terms. Spurred by his central position within his department Hunt has the confidence to confront his superiors rather than evade them. Hunt is a leader who has rallied his troops against the direction the Met is heading, whereas Regan is a lone rebel alienated from his surroundings. 
The CID of The Gentle Touch, however, actively complies with the modernising Met and so sees comparatively little intervention from outside departments. Filling out paperwork and strictly abiding by the law, previously depicted as being ineffectual, is now seen as an integral element of effectively apprehending criminals. As part of this modernising force DCI Russell (William Marlowe) prides himself on treating Forbes as an equal. The only overt misogyny directed at Forbes comes from DI Bob Croft (Brian Gwaspari), whose views are at odds with the rest of the department. When Croft shares Forbes' office in series four his desk is placed at the opposite side of the room. Above Croft's desk hangs a calendar of topless women that overlooks Forbes at her desk. The hanging of this calendar is a statement; Croft confronts Forbes with his view that women exist exclusively for sexual exploitation. The small size of the calendar is however dwarfed by the huge plain walls of the office. Croft's isolated views are insignificant in comparison to the rest of the Met. His view that 'women should be kept at home chained to the stove barefoot and pregnant' is not upheld by others. The positioning of the calendar high on the wall to his right mimics the positioning of Russell's framed portrait of the Queen that hangs in Russell's office in the same position. Whereas Russell is accepting of womanhood in a certain form, Croft dismisses it in all forms. Subsequently Croft's chauvinist attitude and refusal to follow strict procedure sees him disciplined. For failing to keep his diary up to date in 'Be Lucky Uncle' (20 October 1982), Croft faces criminal charges as he is unable to prove that claims made against him are indeed false. Like Regan, Croft is alienated from CID; however, our ideological standpoint lies not with him but the rest of the force. Croft's misogyny and individualistic methods complicate what would otherwise be an efficiently run station. The purpose of the Gentle Touch, then, is to reassure its viewers of a morally objective force, despite the public esteem for the police being at an 'all time low' at that time given the increase in complaints of 'police violence and harassment' towards minorities. ${ }^{7}$ 
Although there is only one misogynist detective in The Gentle Touch, Gamman's argument that the play on sexual difference here is ultimately 'co-opted by the ideology of sexism' still rings true. ${ }^{8}$ In 'Knife' (4 December 1981), DCI Russell dresses down his CID department for indulging in too much paperwork, informing Forbes that he is the 'paper man' and all his staff 'should be operational'. The set design of this CID department space however contradicts this statement. Russell's office is cleansed of paperwork, his office contains a desk, cabinet and wardrobe that are largely empty. Instead paperwork fills Forbes' office whose desk is piled high with folders. Behind Forbes' desk is a bookcase filled with binders, so full that boxes have to be placed on top to cope with the overflow. Above this bookcase, clipboards are hung on the wall displaying information on wanted criminals. These objects, including another bookcase and two further filing cabinets, surround Forbes when sat at her desk. Forbes appears ensconced when encircled by these signifiers of procedure yet no other character is given this treatment. This positioning furthers Gillian Skirrow's view that the purpose of the programme is to examine Forbes 'as an unusual specimen under a microscope'? 9

Although on the whole Forbes is respected by her male counterparts and her opinions are carefully considered, she always concedes to their inherent authority. In 'Something Blue' (5 September 1980) Forbes is concerned that her son is being exposed to pornography courtesy of a schoolmate. Forbes is however informed by DS Jake Barratt (Paul Moriarty) that she should just 'ignore it' because there is nothing in the 1959 Obscene Publications Act that will allow Forbes to prevent people doing what they want in the privacy of their own homes. When Forbes apprehends the pornographic material without a warrant she is subsequently disciplined. According to the ideology of this series, Forbes has allowed her motherly instincts towards her son to cloud her impartial judgement as an upholder of the law. Russell informs Forbes that her actions have put the reputation of the whole squad at risk 
and so forces her to return the material with an apology. Even though The Gentle Touch provides viewers with a moral debate largely absent from action oriented series such as The Sweeney, Forbes has to accept the objectification of women as inevitable within a patriarchal culture. Forbes ultimately conforms to her male colleagues' standpoint as she is unable to change their prejudices. Other than Croft, her colleagues do not express overt misogynistic views but this does not automatically mean that she is immune from sexist stereotyping.

Ashes to Ashes is not co-opted by the ideology of sexism because, much like DCI Jane Tennison (Helen Mirren) in Prime Suspect (1991), Drake is made to prove her capabilities as a woman by working on equal terms with a team of sexist men within a communal office. On Drake's side of the office are two communal desks. Drake works at one desk whilst the other is occupied by another woman, PC Shaz Granger (Montserrat Lombard). Both women are placed together on the opposite side of the office from two principal male characters DS Ray Carling (Dean Andrews) and DC Chris Skelton (Marshall Lancaster). Carling and Skelton have a communal desk each and face their female colleagues. Hunt has imposed a clear gender divide, dominated by a black and white chequered ceiling and matching floor design. Each gender is sat at opposite sides of the chequered office with a big space in between as if they were chess pieces positioned for the start of a match. Drake and Granger are frequently pitted against the male detectives and are required to strategically out manoeuvre them. The women therefore do not automatically concede defeat at the conclusion of each episode and are more aware of misogyny at work and actively challenge it.

Gamman's principal criticism of the Gentle Touch is that Forbes has 'very few professional equals who are not depicted as authoritarian prigs or rivals' thus reinforcing Forbes' 'singularity'. ${ }^{10}$ Essentially, Forbes is a 'special case' and there is 'no suggestion that, given the opportunity, women generally are as capable as men'. ${ }^{11}$ Graham and Pharoah have provided Drake with a confidant in Granger, who frequently proves that her intelligence 
warrants a promotion. In episode 1.4 (28 February 2008), Skelton and Carling are instructed to investigate the meaning of the initials 'RWF' that have been found in a murder victim's diary. Skelton and Carling stride into the office brimming with confidence. Carling grins and points to his chest exclaiming 'we know what it stands for' like a child searching for praise from an adult. All three men are stood in the centre of the office and as Carling is about to reveal what the letters mean Granger's voice interrupts him off-screen causing them to turn round. The camera then cuts to Granger sat at her desk explaining that RWF stands for the 'Revolutionary Workers Front' that 'grew out of International Workers Front when they split from the United Socialist League' who she considers 'Trotskyist' rather than 'antirevisionist'. Before Carling and Skelton enter the office Drake is talking to Hunt. When the men enter the room, however, Drake moves off-screen thus excluding herself from a now exclusively male conversation. Drake remains off-screen until Granger undercuts Carling and brings Drake back into view. The women then must work together strategically to stay active in these male dominated investigations. Granger is usually an ignored figure hunched over the typewriter, with her back to Hunt's office, but here proves that her education would have saved the detectives work. Ashes to Ashes is not solely in favour of fieldwork, like The Sweeney, or more meticulous office based detective work, like The Gentle Touch, and here draws attention to how a combination of both methods would create a more effective CID. Similarly, these two methods are not inherently gender specific. In episode 1.3 (21 February 2008), for example, Drake punches Hunt in the face for insulting her middle-class roots, virtually knocking him from his feet. Incidents such as this, including Drake's competent driving of Hunt's Audi Quattro under pressure, prove that Drake is able to compete with this macho working class masculinity on its own terms.

The objectification of women in Ashes to Ashes is however far more striking than in The Gentle Touch. Granger's small desk space, decorated with photos of architecture and 
artwork to signify her intelligence, is overshadowed by cut outs of semi naked women from soft core publications that litter the entire office. Whereas in The Gentle Touch Croft is a lone figure who tries to undermine Forbes on his own, his small topless calendar being eclipsed by the plain office walls, here all of the male characters share his view and are collectively against Drake and Granger. Having been produced in 2008 Ashes to Ashes is able to look back on 1981 with a critical hindsight. Here the widespread objectification of women, which was hidden behind the immediate surface of The Gentle Touch, is unearthed. This set design further demonstrates McElroy's argument that 'rather than deny the realities of sexism' Life on Mars and Ashes to Ashes do in fact 'actively seek to re-animate the discourse of sexism'. ${ }^{2}$ This is achieved through Drake's character. Drake has a privileged and well informed viewpoint. Having travelled to 1981 from 2008, Drake is more attuned to sexism within the office and is capable of actively destabilising her male colleagues' more obvious biases. In episode 1.3 for example Drake changes her male colleague's preconceptions surrounding prostitution, and educates them on the consequences of their frequent demonisation. A patriarchal society is not an inherent inevitability as Drake can actively contribute to challenging prejudice.

Unable to challenge the patriarchal hierarchy of the CID, Forbes in comparison is only used for certain cases on account of her gentler interrogation methods. In 'Affray' (1 January 1982) for example, after the death of an officer at a student demonstration, Forbes chooses not to intimidate Mary Venn (Sarah James) who is implicated in the crime but kneels down onto the floor, grips one of her hands, and maintains eye contact to reassure her. This patient, personable and gentle way of extracting information is usually successful. This school of interrogation, which Drake also comes from, is a world away from the methods used in the male dominated culture that Hunt subscribes to. In The Sweeney interrogations occur in a sparse basement area of the station amongst the cells. The interrogation room has 
low lighting, white brick walls and a grid of iron bars covers the translucent window. The interrogation space is a cross between an asylum cell and a dungeon. In 'Jackpot' (9 January 1975), Biggleswade (Ed Devereaux), who is apprehended for committing an armed robbery, has managed to hide a large amount of the money in a secret location. In stark contrast to Forbes' interrogation of Venn, this interrogation starts with Biggleswade sat in the corner of the interrogation room clutching his stomach with a cut down his forehead. Carter kneels down beside Biggleswade clenching his fists slowly and maliciously claiming that he is trying to 'refresh' Biggleswade's memory. Biggleswade repeatedly asks for his solicitor over the three day long interrogation but Carter and Regan refuse this right until he tells them where the money is hidden. Regan and Carter have a greater degree of freedom in their interrogations and they only ever adopt a more personable style of interrogation, which includes sitting down to offer Biggleswade cigarettes, not to understand his motives but to threaten him with prison time. Never is this interrogation method considered to be too harsh as Biggleswade is quite simply a hardened criminal deserving of this punishment and eventually Regan is provided with results.

The Sweeney presents these intimidating interrogative procedures as an exclusively male endeavour. The Gentle Touch shows Forbes' personable interrogation methods as being unique to her in relation to her male colleagues. Ashes to Ashes however shows both the ideologically opposed Hunt and Alex interrogating suspects together and compromising between these separate methods of detection. When first interviewing a prostitute named Trixie Walsh (Claire Rushbrook) in episode 1.3 (21 February 2008), who claims she has been raped, Hunt immediately wants to charge her for wasting police time. Hunt insults her appearance whilst sitting at the interrogation room table with his arms folded, his paper and pen untouched. This is in stark contrast with Drake who is constantly poised, sat forward attentively noting down all the details Trixie divulges. Hunt is not as well versed in the 
etiquette that comes with dealing with such claims. It is clear that the audience is supposed to side with Drake in comparison to Hunt who is less well informed of his own sexist prejudice. This is a key scene as Drake's personable and understanding demeanour in comparison to Hunt's impatient aggressions brings to light a case that otherwise would have been dismissed.

There are certain episodes of Ashes to Ashes, however, where the ideology of the series is less clear cut and we can equally empathise with either Drake or Hunt in their very different methods of detection. It is worth examining the key conflicts that occur between Drake and Hunt in episode 1.7 (20 March 2008) to deconstruct the complex ideology at work. In this episode fundraiser Gil Hollis (Matthew Macfadyen) is mugged of his charity money. Firstly, Hunt allows Drake to use her cognitive psychology approach to extract information from Hollis. In the interview room Drake moves her chair to Hollis' side of the table and leans forward. She instructs Hollis to close his eyes, breathe in and out, and picture an orchard brimming with apples. Whilst she does this the camera, positioned in front of them tracks gently, in sync with Michael Jackson's 'One day in your life', around the room until it is positioned behind them. The scene has a somewhat relaxed and even romantic feel as Drake uses this gentle meditative technique to channel Hollis' subconscious. As a result Hollis can remember the colour of his mugger's eyes. Being given the freedom to conduct the investigation on her own, Drake's psychological methods are gradually seen to be extracting key information.

As part of her plan Drake also has Hunt present a television appeal. Hunt is however unable to cope with having to wear make-up and being made the national centre of attention. Hunt becomes too nervous and his superintendent calls the television performance 'pathetic' and 'ineffectual'. Having been made a spectacle of, and impatient with Drake's lack of results, Hunt reasserts his authority of the office space by apprehending a large group of youths seen near the scene of the crime. Drake arrives at the CID office to see it filled with 
suspects. Hunt greets Drake by walking out of his office and punching one of the suspects, stood near Drake, straight in the stomach for goading him with snorts to mimic the sound of a pig. Hunt then picks up this suspect and pins him onto Drake's desk threatening to staple the suspect's hat to his head if he does not answer Hunt's questions. Skelton is taken aback by this excessive violence and Drake informs Hunt that he is 'losing control', his reply being, 'I feel like I'm gaining it'. Excessively reasserting control in this manner does however work as the boy informs Hunt that he and his friends all saw Hollis hide behind the billboard, a significant detail Hollis left out of his statement. Hunt regains control of the office space and claims it as his own by turning it into a brawling space. Threatening the boy on Drake's desk works as a statement, informing her that intellectualising and studying from her desk is not always as effective as more practical methods. This intimidation successfully provides the team with a lead that Drake's gentler approach has thus far been unable to do.

Drake later has Hunt suspended for dislocating Hollis' arm so she can regain control of the investigation. Hunt's instinct is however proven to be true when Hollis attacks all the detectives with a gun at Luigi's restaurant. As Hollis runs away Granger apprehends him, wrestling him to the floor as he tries to extract the hidden charity money from behind the billboard with a Swiss army knife. Granger lands on Hollis' knife. When Hunt arrives with Carling and Skelton she appears dead and so Hunt orders his men to put Hollis on his knees so Carling and Skelton can beat him while handcuffed. As all the men focus their energy on beating Hollis to a pulp, Drake revives Granger. Both the body of Hollis and Granger lie parallel beside one another; the former surrounded by male detectives beating him as Drake kneels beside the latter. A mid-shot captures Skelton's head moving up and down, in and out of the camera frame, in the background as he repeatedly lunges forward to kick Hollis in the stomach. In the same shot, Drake's head bobs up and down in the foreground as she resuscitates Granger. The juxtaposition of movement in this shot epitomises the difference 
between Drake's constructive method of fighting and what happens when testosterone fuelled aggression is left undisciplined. As Granger is brought back to life Drake looks to the skies and emphatically screams that she's 'in control' only to see Hollis beaten half to death. This conclusion to the episode appears to be on the side of Drake who is more in control of her emotions and is able to remain objective. Again this is an interesting twist on the representation of gender in The Gentle Touch as it is now the male detectives whose judgements are clouded by their emotions.

This episode, like many others, has a typical back and forth structure in that Drake and Hunt will attempt to follow one another's methods before repeatedly trying to retain control over the other through any means necessary. Although this ending exposes the consequences of violent conduct in the force it is worth remembering that the reason Granger attempted to apprehend Hollis was because she felt compelled by Drake to prove herself as an equal despite her inexperience in physical fieldwork. Similarly, Hollis would have been arrested earlier if Hunt had been allowed to follow his instinct and Drake had not automatically been so trusting of Hollis from the start. However, it is Hunt's excessive methods that push Hollis over the edge and cause him to confront the detectives with a gun. Then again, perhaps it was Drake's ineffectual procedures that aggravated Hunt's usually contained level of violence. What these various, and equally plausible, readings demonstrate is that in the world of Ashes to Ashes no detective is immune from blame. All of the detectives are implicated in bad decisions as all are presented as fallible human beings irrespective of their gender. Each episode of Ashes to Ashes can be shown to be favourable towards either Hunt or Drake's methods given the circumstances. The frisson that ensues between the two, often heightened by an 'unresolved sexual tension', does, however, always result in a successful arrest. ${ }^{13}$ Throughout The Sweeney and The Gentle Touch paperwork is depicted as being synonymous with women detectives. Drake, although an advocate of 
psychology, proves that women are just as capable as working alongside men in all forms of detection and is able to actively change the attitudes of her colleagues without wholly having to concede to the unfairness of a patriarchal society. The chief superintendent's (Jeremy Clyde) claim that Drake is 'our very own Juliet Bravo' or 'Jill Gascoine' demonstrates the extent to which the ideology of the British police series has been self-consciously reformulated in this programme. Whereas the superintendent, like that of Russell and Croft, can only view women in relation to a particular image or fictional representation, we are given a much more layered form of characterisation. Not only are women just as capable as men, but they are also subject to the same flaws as the men thus putting both genders on an equal footing for perhaps the first time in a British police series.

\footnotetext{
${ }^{1}$ A. Clarke (1992) “"You're Nicked” TV Police Series and the Fictional Representation of Law and Order', in Come on Down? Popular Media Culture in Post War Britain, ed. D. Strinatic and S. Wagg (London; New York: Routledge), p. 244.
}

\footnotetext{
${ }^{2}$ N. Dobson (2012) ““Am I Mad, in a Coma or Back in Time?” Generic and Narrative
} Complexity in Life on Mars', in Life on Mars: From Manchester to New York, eds. S. Lacey and R. McElroy (Cardiff: University of Wales Press), p. 37.

${ }^{3}$ N. Dobson (2012) “Am I Mad, in a Coma or Back in Time?” p. 37.

${ }^{4}$ L. Cooke (2003) British Television Drama: A History (London: BFI Publishing), p. 116.

${ }^{5}$ Quoted in S. Lacey and R. McElroy (2012) 'Introduction', in Life on Mars: From Manchester to New York, eds. S. Lacey and R. McElroy (Cardiff: University of Wales Press), p. 12 .

\footnotetext{
${ }^{6}$ Quoted in M. Alvarado and J. Stewart (1985) Made for Television Euston Films Limited (London: Methuen Publishing), p. 63.
} 
7 C. Emsley (1996) The English Police: A Political and Social History (London; New York: Longman), p. 181.

${ }^{8}$ L. Gamman (1988) 'Watching the Detectives: The Enigma of the Female Gaze', in The Female Gaze: Women as Viewers of Popular Culture, eds. M. Marshment and L. Gamman (London: Women's Press), p. 11.

${ }^{9}$ G. Skirrow (1987) 'Women/Acting/Power', in Boxed in: Women and Television, eds. G. Dyer and H. Baehr (New York; London: Pandora Press), p. 175.

${ }^{10}$ L. Gamman (1988) 'Watching the Detectives', p. 12.

${ }^{11}$ L. Gamman (1988) 'Watching the Detectives', p. 11.

${ }^{12}$ R. McElroy (2012) 'Consuming Retrosexualities: The Past Live On Screen, Online Now', in Life on Mars: From Manchester to New York, eds. S. Lacey and R. McElroy (Cardiff: University of Wales Press), p. 119.

${ }^{13}$ J. R. Cook and M. Irwin (2012), “"Moonage Daydreams” Nostalgia and Cultural Memory Contexts of Life on Mars and Ashes to Ashes', in Life on Mars: From Manchester to New York, eds. S. Lacey and R. McElroy (Cardiff: University of Wales Press), p. 84. 